\title{
Motivational Preferences of the Managers in Production and Promotion of Innovative Materials and Technologies
}

\author{
Nadezda Miloradova ${ }^{1, *}$, and Alexander Ishkov $^{1}$ \\ ${ }^{1}$ Moscow State University of Civil Engineering, 129337 Yaroslavskoye shosse 26, Moscow, Russia
}

\begin{abstract}
The article discusses the results of the comparative analysis of motivational profiles of managers, who work in the construction industry with innovative materials and technologies. In Russian construction industry the innovative building materials and technologies are being introduced slowly because of many reasons: the absence of a clear state policy in construction industry, dependence on the estate market. The purchasing possibility of the population is low. However, the innovation requires an appropriate motivational spirit of managers: "Interest and usefulness", "Creativity", "Achievement", "Variety and change".
\end{abstract}

\section{Introduction}

Productivity, efficiency and quality of labor activity depend not only on the qualifications of the staff, but also of their motivation. It is not surprising that employers prefer to highly motivated individuals whose motivational preferences are corresponded to the company organizational goals. Managers and leaders dream of working with highly motivated team, where its members have the same motivational orientation.

Now effective management is impossible without the knowledge about the origin of motivation, without the ability to recognize motivational preferences. The modern world provides wide opportunities to find work and people are actively using this opportunity. People want employers need to take into consideration their interests. Therefore, the heads tasks are to find motivated staff and keep the most valuable employees.

People always were interested in the origin of motivation and methods for the recognition of motivational preferences. The problems of motivation are actively discussed and studied in various social sciences: philosophy, sociology, history, management and others [1-3]. For the last century quite a lot of psychological theories of motivation were developed, many hundreds of empirical studies were carried out [4;5].

In the motivational structure of human personality motives occupy different positions: some of them are major, defining human activities and behavior, the others are dominant, being the total emotional and motivational background, and another's are latent (hidden, implicit) [6].

* Corresponding author: milordos@gmail.com 
Motivation is significantly associated with the development of society: the material and ideal objects, the person is ready to work for, change under the influence of society changers. The list of motivating factors is constantly expanding, changing. During the life a number of motivating factors person implements at the same time. His motivational sphere is fluid and converted [7].

Search of the motivating factors most often is conducted within the framework of hierarchical models of motivation by A. Maslow [8]. According to this theory, humans have five levels of needs: physiological, security, social, esteem and self-actualizing. In modern classifications of needs the first two levels are combined into one - the low (physiological). This level presents human needs of wage, financial rewards and comfortable working conditions. Today this level is considered just a condition of human survival, not motivation.

In the early XX-th century psychologists began to pay special attention to the social needs of human: public recognition, contacts with colleagues, etc. These motivating factors were considered important to a human regardless of the position which he occupies [9].

In the XXI-st century the values of the contemporary world community have had significant changes. The development of information technology leads to more individualization of work and as a result, the role of social motivation is reduced. The motivators of psychological (personal) level became the most important among the all motivators: commitment to diversity, changes or stability of structure; creativity and selfimprovement [10].

The production and promotion of innovative materials and technologies is developing intensively $[11 ; 12]$. However, as the practice shows, innovations in the Russian's construction sphere are introduced in the last turn. As the innovative analytics, the main obstacle for the development and implementation of innovative technologies in the construction industry is the lack of clear state policy in the field of construction. One more reason of "innovative slowness" of construction industry is the fact that it is rigidly integrated in the real estate market, which does not seek to introduce a radical technological innovation. The purchasing power of the population is low, so cheap housing are constructed $[13 ; 14]$.

In addition to the technical side of the development of innovative technologies, there is another side. This is the mentality of the people and their desire and ability to create something new and willingness to implement the new product. Russian people learn quickly, they are interested in new technologies and building materials, ready to accept innovation complex. They are aware of everything new that is being developed in other countries. But the question is whether they are ready to introduce new building materials and innovative technologies in the construction industry in their country. Sociological studies show that, on one hand, the residents are interested in high-quality innovative products. On the other hand, the Russian tendency of investor or the company's executive is to use the cheapest building material and technology. It should be noted that there is a "dictatorship" of builders in Russia, because the market is not saturated, the demand exceeds the supply a lot. The purchasing possibility of consumers is low [15].

The effectiveness of innovation venture involves the creation of a special organization culture, in which they have common motivational basis, focuses on the optimal combination of motivating factors $[16 ; 17]$.

Researches of motivating factors of the managers have a particular meaning, because these people are forming the organization culture [18]. They are "trendsetters" in their organization: they implement their own ideas about the motivating factors that encourage some motivators and impede the implementation of others among subordinates. 


\section{Hypothesis}

Development of innovative building materials and technologies, their promotion on the construction market and the widespread use in mass construction industry, the managers of these processes have such leading motivating factors as "Interest and usefulness", "Creativity", "Achievement", "Variety and change". This combination of motivators creates the unity of the motivational basis of man, leading him to the solution of creative tasks and the implementation of results of innovative searches.

The purposes of the research are:

1) description of motivational profile of Russian managers, who work in construction industry;

2) to make comparative analysis of motivational profiles of Russian and European managers.

\section{Research methodology:}

The test-questionnaire by Sheila Ritchie and Peter Martin has been selected to research a motivational profile [10]. Among the huge number of psychological tools to identify motivational preferences, the work of these authors has attracted our attention for several reasons.

Firstly, these authors have their own 12-factor model of motivational profile. In this model, traditional motivators (physiological and social) and also some new - psychological motivators are presented. Each motivator is described in detail.

Secondly, more than thousand managers from various European countries were tested by this test-questionnaire. The results of research by these British authors are presented in detail in their book. The results of the test-questionnaire may be presented in a graphical form as the motivational profile.

Russian version of the questionnaire adapted by A. D. Ishkov contains 33 statements, which have four possible answers each [19].

The study of motivational preferences has been hold in Moscow State University of Civil Engineering (MGSU) since 2004. During these years thousands of students from different faculties and more than 500 people, who attend (a) short training courses for managers of investment and construction sector and b) the two-year MBA program "Financial management", took part in this study.

This research was conducted in MGSU from 2014-2016.

The study involved:

- twenty seven top-managers aged from 34 to 46;

- fifty three middle managers at the age between 27 and 53 .

\section{Results of the research}

Data obtained in the research were summarized and presented in graphical form (Fig.1) together with the results about Europeans managers received by W. Richie and P. Martin. 


\section{Median}

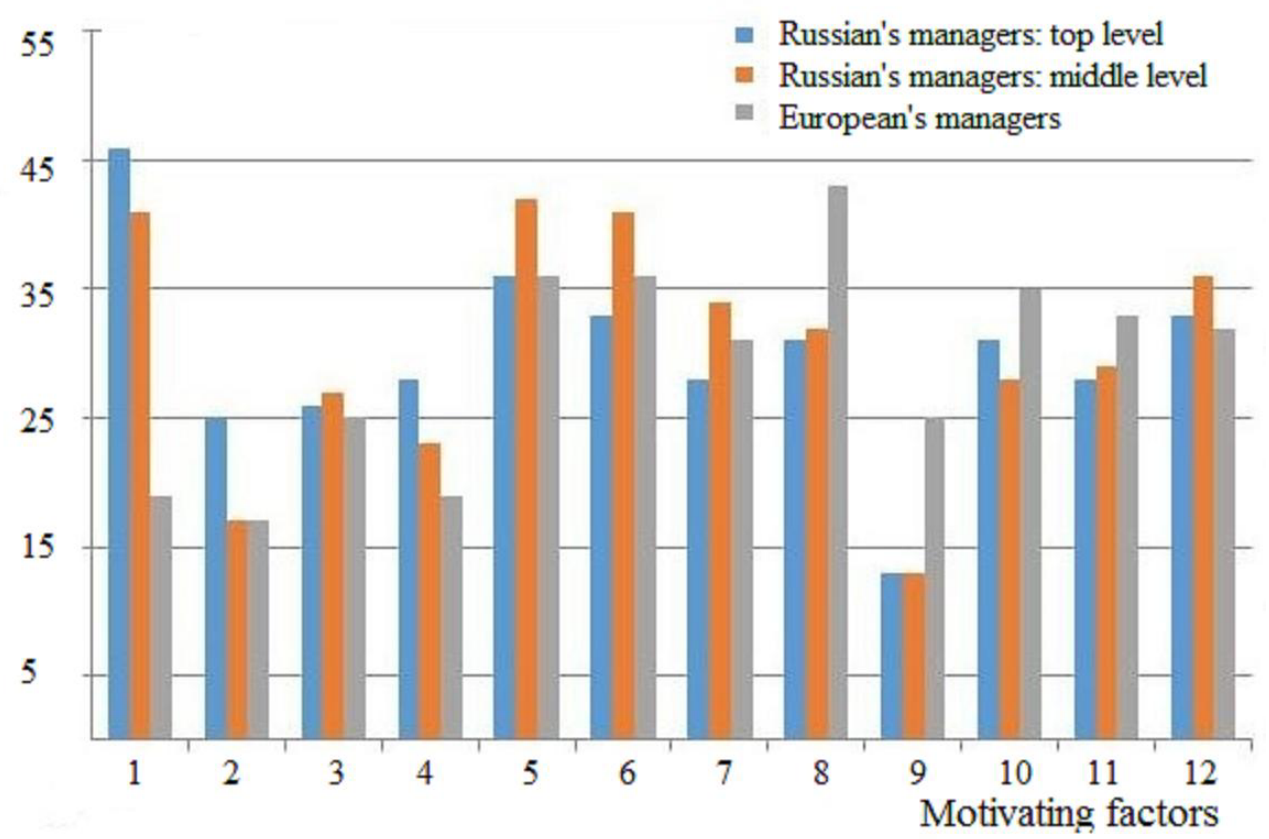

Fig. 1. Motivational profiles managers.

Motivational profile according to the method of W. Richie and P. Martin consists of twelve motivators, represented by corresponding numbers:

1. Money and tangible rewards.

2. Physical condition.

3. People Contact.

4. Relationship.

5. Recognition.

6. Achievement.

7. Power and Influence.

8. Interest and usefulness.

9. Structure.

10. Variety and change.

11. Creativity.

12. Self-development.

As we can see from the figure, the profiles of the Russian and Europeans managers vary considerably.

The results of research of Russian managers (top level) are: the leading motivator for them is only "Interest and usefulness". They are followed by motivators with the different degree of expressiveness: "Recognition", "Desire to achieve", "Self-improvement", "Commitment to Diversity and Change" (Figure 2). The motivators "Physical conditions of work" and the "Desire for structuring and procedure" located at the end of the motivational preferences list. These motivators, as shown in the research results, are initially insignificant. They said: "Constructions does not expect comfortable working environment and ideal order! Constructions is not the office, where people work with the papers!" 


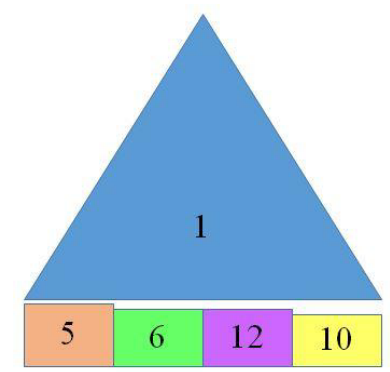

Fig. 2. The main motivators of Russian managers (top level).

The results of research of Russian managers (middle level) are: they have three leading motivators such as "Recognition", "Money and tangible rewards" and " Achievement." They are followed by the motivators with different degree of expressiveness: "Selfdevelopment", "Power and Influence", "Variety and change " (Fig. 3.) The same motivators "The physical conditions" and the "Structure", which top-managers are had at the end of the middle level managers motivational preferences list.

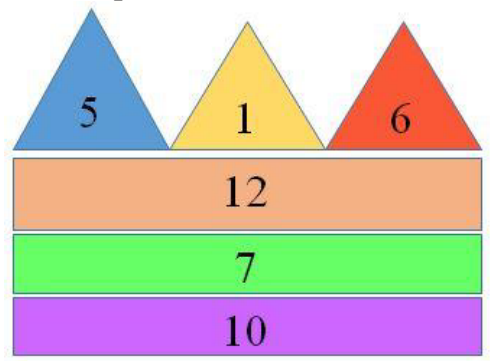

Fig. 3. The main motivators of Russian managers (middle level).

The results of research of Europeans managers by S. Richie and P. Martin are: the leading motivator for them is only "Interesting and useful work". They are followed by a motivators with almost the same degree of expressiveness: "Recognition", "Achievement", "Variety and change" and a little behind them is "Creativity" (Fig. 4). The motivators of physiological level "Money and tangible rewards", "The physical conditions " and "Relationship" are at the end of the motivational preferences list. As S. Richie and P. Martin noted, it is an indicate that these requirements have already been satisfied. These manages reached the financial level, which they considered appropriate for them. So these motivating factors don't determine their behavior any more.

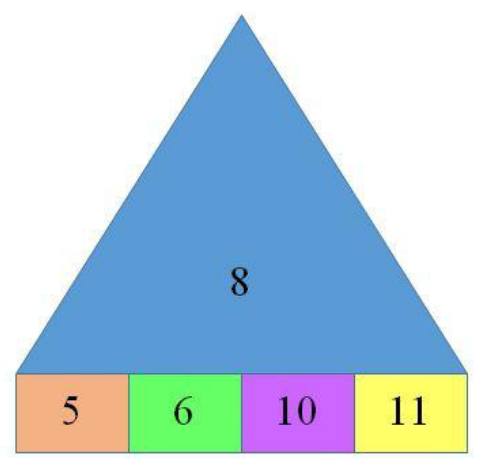

Fig. 4. The main motivators of Europeans managers. 
The need of "Money and tangible rewards" is a leading motivating factors for the majority of Russian managers of all levels. The motivational profile of the university students in the construction direction is similar. This tendency has not changed during twelve years of studying motivational preferences. The attitude to such motivators as "Structure", which in the desire to work according to the rules, has not changed. As a "justification" Russian managers believe, that strict regulation prevents the creative process and don't inspire new ideas [20].

Thus we can state that the necessary conditions for development of innovations have at least two options: "Interesting and useful work' as a leading motivator and high level of such motivating factors as "Creativity", "Variety and change ", "Achievement". These motivating factors support the leading motivator. If these conditions are not observed, the innovative activity is really slow.

\section{References}

1. E.E. Lawler, Motivation in work organizations (Books/Cole Publishing Co, Monterey, Calif, 1973)

2. M.R. Ryan, E.L. Deci, Contemporary Educational Psychology, 25(19), 54-67 (2000)

3. C. Wiley, International Journal of Management, 18(3), 263-281 (1997)

4. G.A. Cole, Management - Theory and Practice (South-Western Cengage Learning, London, 2004)

5. F. Storseth, International Journal of human Resource Development Management, 4(3), 267-287 (2004)

6. D. Kun, Osnovy psikhologii. Bol'shaya entsiklopediya. Vse tayny povedeniya cheloveka (Praym-Evroznak, Sankt-Peterburg, 2008)

7. Z. Ivanova, I. Pichugin, J. Naimaviciene, Procedia Engineering, 117, 154-161 (2015)

8. A. Maslow, Motivation and personality (Harper, New York, 1954)

9. E.V. Romanova, EHkonomika i predprinimatel'stvo, 6-3, 793-796 (2015)

10. S. Ritchie, P. Martin, Motivation Management (Gower Pub Co, London, 1999)

11. A.D. Ishkov, A.V. Stepanov, S.V. Miloradov, I.V. Voronina, Applied Mechanics and Materials, 670-671, 458-461 (2014)

12. A.D. Ishkov, D.A. Semernin, S.V. Miloradov, I.V. Voronina, Applied Mechanics and Materials, 741, 500-503 (2015)

13. Information on https://imi.hse.ru/pr2013_1

14. E. Shnyrenkov, I. Pryadko, Procedia Engineering, 117, 330-335 (2015)

15. Information on http://www.gks.ru/bgd/regl/B12_46

16. A.D. Ishkov, M.Y. Mishlanova, K.P. Grabovyi, International Journal of Applied Engineering Research, 11-3, 1676-1679 (2016)

17. E.A. Lyubushina, E.V. Romanova, EHkonomika i predprinimatel'stvo, 6-3, 925-928 (2015)

18. T.N. Magera, Vestnik MGSU, 6, 527-532 (2011)

19. N.G. Miloradova, A.D. Ishkov, Ekonomika i predprinimatel'stvo, 5-2, 891-896 (2014)

20. N.G. Miloradova, A.D. Ishkov, Psikhologiya upravlencheskoy deyatel'nosti: izmenenie podkhodov (Flinta, Moscow, 2014) 